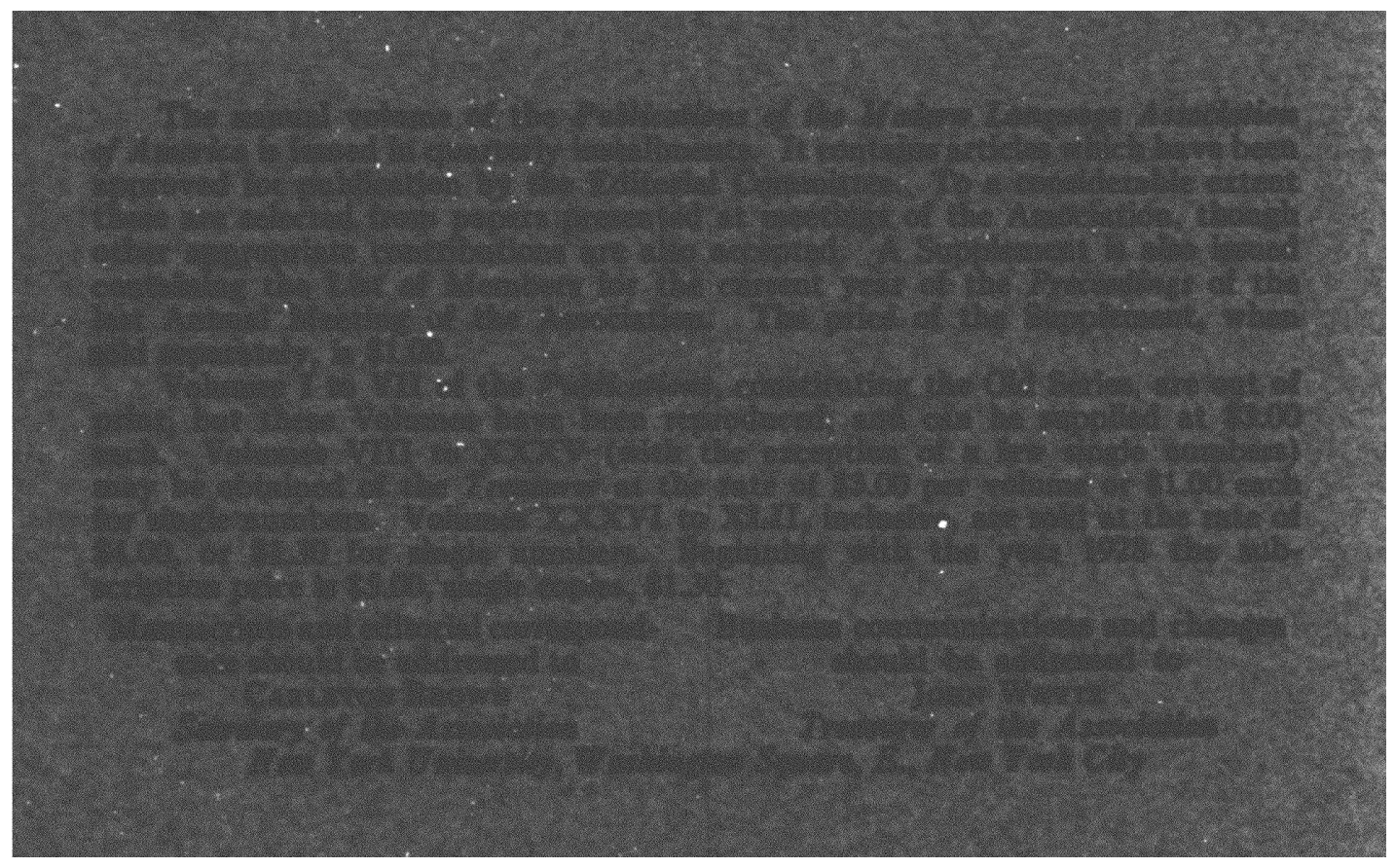




\section{NEW TEXTS}

You are invited to examine any of the books mentioned below, with a view to class adoption. We shall be glad to serve you.

\section{World Drama Series -seven volumes}

Edited by Robert Metcalf Smith, Pr.D., Professor of English, Lehigh University.

This is the first series of Anthologies of World Drama arranged according to type. The editor has emphasized those qualities of permanent interest which make the dramas masterpieces. A chronological arrangement within each volume has been observed. The Introductions written for each volume and, in most cases, for each play, include careful definitions of types of drama.

\section{Shakespeare and}

His Fellow Dramatists - two volumes

Edited by E. H. C. Oliphant, M.A., Senior Fellow in English, Sarah Lawrence College.

This comprehensive work gathers the finest fruit of the dramatic era from the accession of Queen Elizabeth to the closing of the theatres. Contains 45 plays arranged in chronological order. Each play is preceded by a full and critical introduction.

Price \$4 per volume

\section{Medieval Narrative}

A Book of Translations, by Margaret Schlauch, Pr.D., Assistant Professor of English, Washington Square College, New York University.

Presents a scholarly piece of work and adequate material for a course in medieval literature. $456 \mathrm{pp}$. Price $\$ 2.50$ per volume

\section{Prentice-tall, tac}

20 Fifth Avenue, now York, n. $\mathfrak{q}$. 


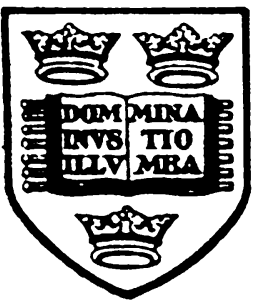

\title{
The Sign of Erudition
}

Since 1468

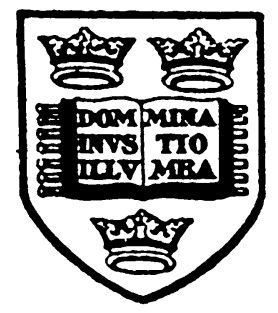

\section{THE CONTEMPORARY FRENCH SERIES}

A series of inexpensive volumes containing selections from Anatole France, Marcel Proust, Pierre Loti, Paul Margueritte, and Daudet, all edited with notes and vocabularies.

THE OXFORD BOOK OF REGENCY VERSE

1798-1837

Chosen by $\mathrm{H}$. S. Milford

The newest Oxford Book of Verse
MODELS AND VALUES

Chosen by Walter PriLLIPS, WiLliAM G. CRANB and Frank R. BYErs

$A$ Course of Reading for Students

\section{THE OXFORD STANDARD EDITIONS OF POETRY AND PROSE}

Well printed volumes in handsome deep blue bindings, providing scholarly and accurate texts of the great English classics, these books serve equally well for college texts and for personal libraries.

\author{
Request examination copies from \\ Educational Department \\ OXFORD UNIVERSITY PRESS
}

114 Fifth Avenue

NEW YORK 
The Educational Department of E. P. Dutton \& Co., Inc., wishes to express to members of the Modern Language Association of America its appreciation of the enthusiastic reception that has been accorded to many of the Dutton Modern Language Texts. Such Series as The Muses Library, The Temple Classics, Everyman's Library and The Kings' Treasuries of Literature need hardly be mentioned to find hosts of friends. And the speech of the Nation has lost many regional eccentricities since the Jones English Pronouncing Dictionary and the Ripman phonetic books have been introduced in American classrooms. The Treasuries of French Literature and of German Literature, both prose and verse, have taken instructors by storm as they possess features to recommend them to the most particular people. Ritchie and Moore's anthologies: French Verse from Villon to Verlaine and French Prose from Calvin to Anatole France are especially popular as they serve to familiarize the student with the whole field of French Literature by means of passages that lead to more extensive reading. The Kastner and Marks New Course in French Composition, issued in three parts for beginners, intermediate and advanced students, finds many advocates while various elementary books build such a firm foundation that College Board Examinations have lost their sting. Details of these and many other excellent texts for language students may be obtained by addressing the Publishers at Three Hundred Fourth Avenue, New York City, N.Y.

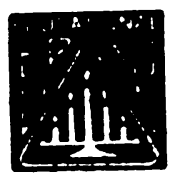




\title{
THE FUNERAL ELEGY
}

AND THE RISE OF ENGLISH ROMANTICISM

$A$ Contribution to the History of Culture in the Seventeenth and Eighteenth Centuries

\author{
By JOHN W. DRAPER, Ph.D.
}

T $\mathrm{BE}$ swift and fundamental transformation-intellectual, literary, artis1 tic-from Neo-Classicism to Romanticism in Eighteenth-Century England, Professor Draper presents as due to the sudden rise of the bourgeoisie, first through foreign trade and, later, through the Industrial Revolution. Drawing upon new sources of evidence, Professor Draper shows the social, religious, and psychological changes in the middle class immediately before and during the earlier stages of this upward trend; and plots the steps of their emergence from Calvinism, and of their increasing artistic patronage. The FUNERAL ELEGY, by showing the divergent attitudes of different social classes toward death, life, and immortality, becomes a clue for the interpretation of socio-psychology and of the evolution of thought, literature, and the arts. Professor Draper's presentation of this evolution is a notable example of that type of scholarship which, not cortent to tell what happened and how it happened, tells also, in terms of underlying social causes, why it happened.

8vo, xvi 350 pages; bound in blue cloth, gold lettered; choicely illustrated. Price $\$ 6.50$

\section{THOMAS SHADWELL: His Life and Comedies}

\section{By ALBERT S. BORGMAN, Ph.D.}

Tr homas Shadwell is one of the unluckiest figures in the literary I history of the seventeenth century. Poet-laureate to William and Mary, friend of many of the wittiest men of his age, dramatist who could count more successes than failures, he, nevertheless, is remembered as one who "never deviates into sense." Dryden's satirical lines-among the most trenchant ever penned-have given Shadwell an unenviable reputation. But no person who has read with an open mind even the least happy of Shadwell's comic ventures can properly dismiss him as dull.

In this monograph, Professor Borgman brings together the facts of Shadwell's life, some of which are here presented for the first time, and discusses each of the thirteen comedies-their relationship to earlier and contemporary drama, and their echoes of the life of Restoration England. The result is an important contribution to our understanding of an important period.

8vo, $x+270$ pazes; bound in blue cloth, gold-lettered. Price $\$ 5.00$

\section{THE NEW YORK UNIVERSITY PRESS Washington Square East NEW YORK CITY}




\section{New Romance Language Textbooks}

\section{FRENCH}

Dumas: Le Comte de Monte-Cristo (Brandon and Skinner)

Dumas: Le Vicomte de Bragelonne (Hamilton)

Erckmann-Chatrian: Le Trésor du Vieux Seigneur (Robert)

France: Les Enfants (Smith and Johnson)

Malakis: Intermediate French Functional Grammar and Conversation

Moussiegt and Dickman: Introduction to French Free Composition

Rolland: L'Aube (Jean-Christophe Vol. I) (Church)

$$
\text { ITALIAN }
$$

Marraro: Contemporary Italian Short Stories

\section{SPANISH}

Castillo and Watson: Spanish Tales and Fables Valle-Inclán: Jardin Umbrio

\section{HENRY HOLT AND COMPANY Incorporated}

New York Boston Chicago San Francisco 


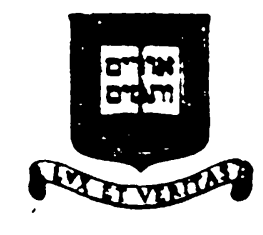

\title{
Incomes and Living Costs of a University Faculty
}

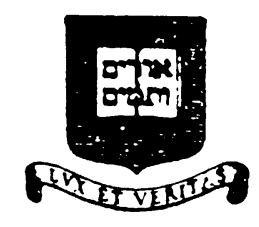

With a Foreword by

JAMES ROWLANd ANGELL.

President of $Y$ ale University

Edited by

YANDELL HENDERSON

Maurice R. Davie

This volume, which is certain to arouse widespread discussion, reports the results of a special survey conducted among members of the faculty of Yale University, and throws light on the academic standard of living and the cost of maintaining that standard.

President Angell says in his foreword: "the problem presented by academic salaries is, in many ways, the most urgent now confronting American Education."

Price $\$ 2.00$

\section{Sketches of Eighteenth Century America}

\author{
By St. John de Crevecoeur
}

\section{Edited by}

Henri L. Bourdin, Ralph H. Gabries, Stanley T. Williaks

The "additional letters" which Crevecoeur referred to in his "Letters from an American Farmer" are found in this volume. Crevecoeur was not an historian but a chronicler of unrelated episodes. His chief interest was in people; his acute powers of observation, his wide contact with men and communities, and his rare blend of the emotional and intellectual, combined to render his judgment sane and his picture vivid and clearcut.

\section{Price $\$ 4.00$}

\section{YALE UNIVERSITY PRESS}

New Haven

Connecticut 


\section{Attractive French and Spanish Texts for Beginners}

\section{Le Tour de la France (Wilson)}

A charming tale of two boys who travel over France seeing the country and recording their impressions.

\section{Contes et Légendes-Part One (Guerber-Crosse)}

A collection of legends and fairy tales intended as an introduction to genetal French reading.

$\$ 0.96$

\section{La Tache du Petit Pierre (Manley)}

The dramatic story of a little orphan who regains the family honor and fortune after many struggles and adventures.

\section{Petits Contes de France (Méras and Roth)}

$\$ 0.64$

Real French stories in which French thought, character, and ideals are simply and clearly portrayed.

$\$ 0.84$

\section{Amparo (Ray and Bahret)}

A wholesome Spanish story of love and adventure which has an interesting and varied plot.

$\$ 1.00$

\section{Fortuna and La Golondrinita, El Gato y el}

\section{Mono (Bahret)}

The first is one of the most popular dog stories showing. the attachment between a dog and a small boy. The secund story is very entertaining with much lively humor. $\$ 0.92$

\section{Lecturas para Principiantes (Ray)}

This attractive story of two children and their uncle gives a wide range of information about the customs, commerce and traditions of Latin America.

$\$ 0.92$

\section{A First Spanish Reader (Roessler and Remy)}

Composed of many brief and simple sclections, including interesting anecdotes, short stories, fables in verse, lessons on geography, etc.

\section{AMERICAN BOOK COMPANY}

New York Cincinnati Chicago Boston Atlanta 
ESSAYS

\section{CHALLENGING} ESSAYS

IN

\section{MODERN THOUGHT}

7 HIS is a volume of provocative essays, suggestive 1 questions, and representative student themes, compiled and edited by Joseph M. Bachelor, associate professor of English at Miami University, and Ralph L. Henry, assistant professor of English at Carleton College. The book is intended, first and foremost, to start an argument in the freshman composition class; to prod the student's intellect and guide his thought through channels of liberal thinking.

Supplementing each of the thirty-two essays included in the volume is a representative student's theme, which is an example of what can be expected of the average college freshman. The purpose of these themes is to stimulate competition: they are a challenge to the ability of each student.

Questions and a rich supply of theme topics have been included in the book to aid the student and to lighten the instructor's work. The questions are designed to bring out the salient points of each essay. The theme topics are intended to help in limiting the discussions and themes to the phases of most appealing individual interest.

\section{Price $\$ 2.00$}

\section{THE CENTURY CO.}




\section{The Elizabethan Jig and Related Song Drama}

By Charles Read Baskervill

Because its popularity lay with the people the sixteenth and seventeenth century jig was neglected, even scorned by the cultured. As a result, few specimens have survived and the history of the form has been difficult to reconstruct. This is the first complete account of this type of drama in England.

$\$ 5.00$

\section{Folklore in the English and Scottish Ballads}

By LOWRY C. WIMBERLY

Mr. Wimberly stresses the content of the ballad rather than the form; he shows that the British ballads are repositories of genuine folk belief. $\$ 5.00$

\section{Swindlers and Rogues}

\section{in French Drama}

By HILDA NORMAN

Using one hundred and eighty-five plays, Miss Norman traces the money question through three centuries of vaudevilles, comedies, and dramas.

$\$ 3.00$

\section{A Balzac Bibliography}

Compiled by William Hobart Royce

The only bibliography on Balzac which embraces writings in more than a dozen languages; the only one which presents the information in complete bibliographical form; the only one which is up-todate, the only work, in fact, which in its comprehensiveness may be called, "A Balzac Bibliography."

\section{The University of Chicago Press}




\section{The \\ Albert Teachers' Agency}

25 B. Jactoon Boulevard

CHICAGO, II.

Established 1885

This Agency has been successful in placing many teachers and professors of Romance Languages, Classics and English in desirable positions. During the past year, we filled an unusually large number of positions at salaries ranging from $\$ 1500$ to $\$ 3900$, and several at $\$ 7,000$. If you want to capitalize your training and experience it would be wise to avail yourself of our facilities. In our Chicago office our Managers do departmental work. One of these devotes much of his time to the placing of Language teachers. He knows the field and keeps in touch with the better grade of institutions. The Albert Teachers' Agency was established in I885, is still young and yearly adding to its clientele. This continuous growth is the result of live wire methods, highest degree of efficiency, strong organization, all with an eye single to giving satisfactory service. If interested in securing a promotion, come to us early.

Other Offices:

NEW YORK WICHITA SPOKANE 


\section{THE CENTURY MODERN LANGUAGE SERIES}

\section{FRENCH COMPOSITION AND CONVERSATION}

By Joseph Brown, Jr. (Western Reserve University) and Dwight Ingersoll Chapman (De Pauw Lniversity). This admirable text is designed to equip students who have had the equivalent of twelve hours of college work in French with the knowledge of vocabulary, idiom, grammar, and syntax which will enable them to have the language at their command when they need it. It presents the living language as it is spoken and written in France today.

$$
\text { I2mo, ix+199+6I pages, illustrated. } \$ 1.60
$$

\section{FRENCH LITERATURE IN OUTLINE}

This is a conveniently arranged handbook, prepared by PHILIP H. Churchman (Clark University) and Charles E. Young (State University of Iowa). It presents, in English, in chronological order by periods, all the more important facts relative to the history of French literature. The typographical arrangement is such as to make possible quick and easy reference. Guiding questions indicate what the students may be expected to know after a study of the outline.

$$
12 m o, x+322 \text { pages. } \$ 1.60
$$

\section{EIGHTEENTH-CENTURY FRENCH PLAYS}

This handsome volume, edited by Clarence D. Brenner (Princeton University) and Nolax A. Goodyear (Emory University), presents in French fifteen typical plays illustrating the works of the outstanding French dramatists of the eighteenth century. Each playwright is represented by the play generally regarded as his most significant achievement, excepting Voltaire who is represented by two plays-a tragedy and a comedy.

$$
\text { Royal octavo, } x x i i+561 \text { pages. } \$ 4.25
$$

THE CENTURY CO.

353 Fourth Avenue, New York City

2126 Prairie Avenue, Chicago 


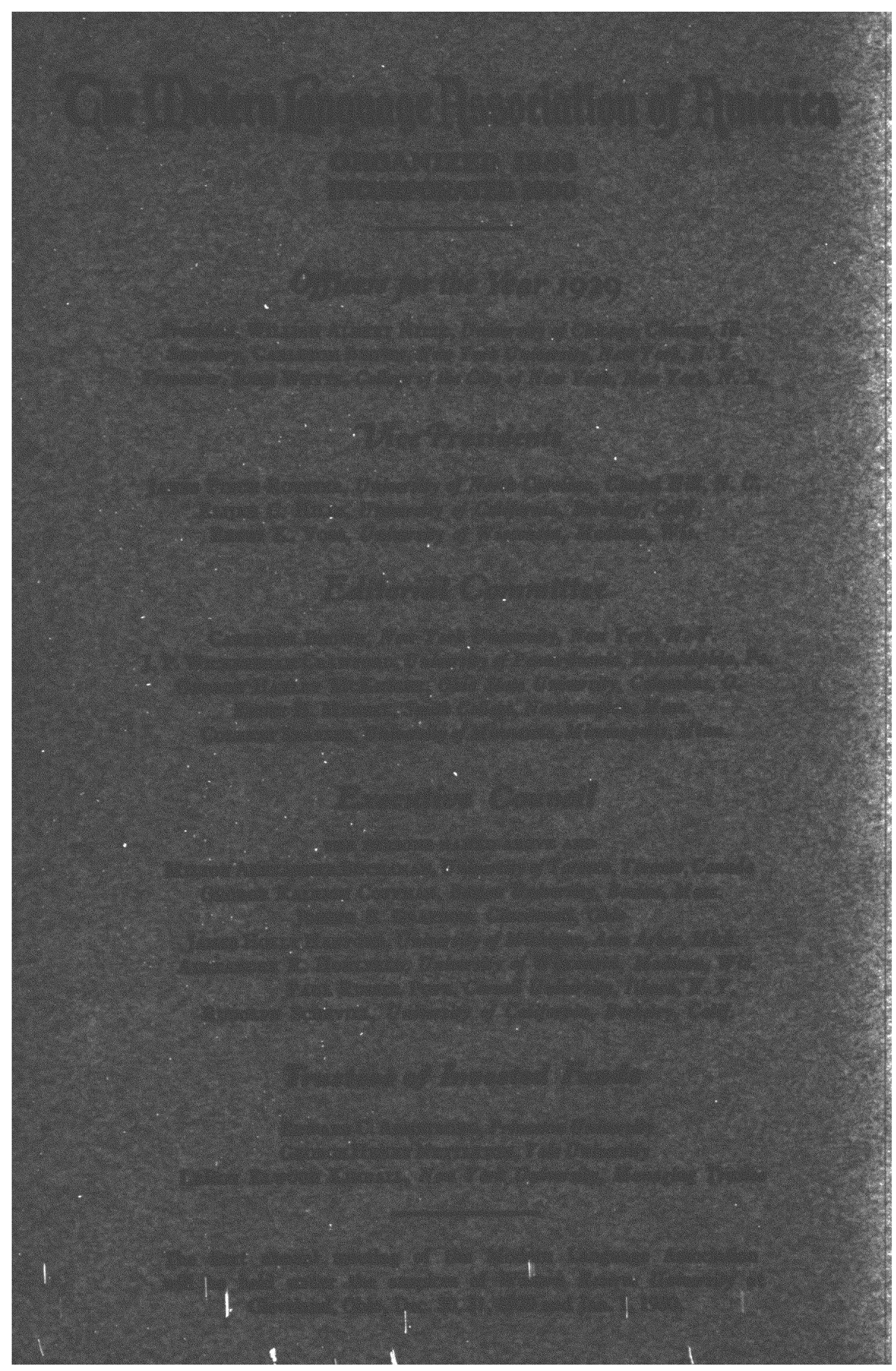




\title{
Publications
}

\section{of the \\ Modern Language Association of \\ America}

\author{
EDITED BY \\ CARLETON BROMN \\ SECRETARY OF THE ASSOCIATION
}

VOLUME XLIV

PUBLISHED QUARTERLY BY THE ASSOCIATION

PRINTED BY GEORGE BANTA PUBLISHING COMPANY

MENASHA, WISCONSIN

1929 